\title{
Assessment of Financial Performance and Efficiency of Islamic and Traditional Banks in the Post-Crisis Period
}

\author{
Slaiman Alebrahim ${ }^{1}$ \\ ${ }^{1}$ The Public Authority of Applied Education and Training, College of Business, Kuwait \\ Correspondence: Slaiman Alebrahim, The Public Authority of Applied Education and Training, College of \\ Business, Kuwait. E-mail: slaiman.tk@gmail.com
}

Received: October 3, 2019

Accepted: October 30, 2019

Online Published: November 10, 2019

doi:10.5539/ijbm.v14n12p149

URL: https://doi.org/10.5539/ijbm.v14n12p149

\begin{abstract}
Much of the research surrounding Islamic banking has focused on the 2008 financial crisis and the distinctions between conventional and Islamic institutional performance. Given the consensus that due to lower risk profiles and higher efficiency performance, Islamic banking outperformed its conventional counterparts during that tumultuous period, it is important to extend the academic focus beyond this narrow timeframe. The current investigation has applied a systematic methodology to review quantitative data from several emergent studies regarding post-crisis performance comparisons between Islamic and conventional banking institutions. At the risk of regional or institutional bias, these findings have demonstrated a higher degree of volatility in technical and scale efficiency amongst Islamic institutions since 2010, yet simultaneously, a higher overall efficiency rate of 0.886 when contrasted with the average total efficiency of 0.771 in conventional banks. The evidence highlights a positive correlation between the risk-adverse investments utilised by the Islamic banking system, but suggests that there is significant opportunity for growth through network consolidation and institutional expansion in order for these banks to take advantages of regionalised economies of scale.
\end{abstract}

Keywords: Islamic banking, performance, efficiency, growth, institution, investments, finance

\section{Introduction}

\subsection{Problem Overview}

In the wake of the 2008 financial crisis, banks across the global community have endured a period of procedural investigation as regional regulatory agencies have struggled to introduce policies and tolerances capable of preventing a similar crisis in the future. Whereby the novelty of Islamic banking has widened the scope of interest in the potential advantages or benefits of this revisionary formula, Belanes et al. $(2015, \mathrm{p} .82)$ suggest that academics are undertaking to actively 'test the viability' of this banking system in direct comparison to conventional banking practices. Citing evidence from a long-term study, for example, Chapra (2008) observed fiscal superiority in Islamic banking over its conventional counterparts during several periods of economic instability including the US stock market crash of 1987, the Asian crisis of 1997-1998, the long-term capital management (LTCM) crisis of 1998, the dot.com bubble in 2000, and finally, the global financial crisis in 2007-8. Subsequent research by Boumedine and Caby (2009) further confirmed that Islamic banks were more protected from the financial exposure of conventional banks during the crisis period in spite of the fact that the consequences of the economic downturn had a negative impact on their performance as well.

This sense of distinction between Islamic and conventional banking performance has motivated researchers to consider the underlying causes for performance advantages and higher efficiency levels as Islamic banking expands across the global community into a range of conventional markets. Empirical evidence presented by Faye (2013) and Bitar (2017) regarding the institutional stability and pre, during, and post-crisis performance suggests that Islamic banks have continued to outperform their conventional counterparts across the global marketplace in spite of the structural flexibility of the investment instruments and strategies deployed within the conventional banking system. Further, Aleakis et al. (2019) have confirmed that due to risk-adverse practices and restrained investment modalities, Islamic banks not only outperformed conventional banks during the financial crisis, but recovered from the economic downturn at a quicker, more efficient rate. With many Islamic and conventional banks operating in similar markets, there is a need for greater understanding of what factors are contributing to such performance advantages, and what solutions are available for Islamic banks to expand their 
position in order to compete more directly with their conventional counterparts.

\subsection{Importance of the Research}

For institutional leaders and industry regulators, the enigma of Islamic banking has raised myriad questions regarding the post-crisis performance of this socially, culturally, and religiously important form of financial governance. Whilst Islamic banking institutions may be structurally advantaged during financial crisis conditions, it is important to determine whether such advantages remain during regular periods of economic growth or relative financial stability. The weight of the financial crisis, however, has resulted in multiple investigations and studies that have prioritised intra-crisis performance and institutional stability, failing to consider the post-crisis performance advantages of Islamic finance in normative practice. Accordingly, the current study was undertaken to synthesise the literature related to this period of growth and stability, drawing upon a narrow band of quantitative studies that can be used to illuminate the sustained advantages (and potential limitations) of Islamic finance management practices. The aim of this research was to compare the profitability and efficiency of Islamic and traditional banks between the post-crisis period of 2010 and 2016 in order to determine particular variations and performance indicators which may suggest variations in institutional risk profiles.

\subsection{Review of the Relevant Literature}

The distinction between conventional and Islamic banking has been simplified into two primary deviations: conventional banking systems earn profits from the 'interest rate spread between borrows and depositors' whilst Islamic banking profits are based upon a profit-loss sharing settlement with the depositors and borrowers (Ara, 2016, p.64). Core investment vehicles that are associated with the conventional banking business model such as derivatives, speculation, and interest-bearing investments are not supported in the Islamic banking mode, as central governance principles prohibit riba (usury), gharar (Excessive uncertainty and risk), and illegal or illicit activities (Abdul-Majid et al., 2017). To achieve their commercial objectives, Islamic banks instead rely upon murabahah (cost plus) financing, mudaraba (profit sharing), or musharaka, (profit and loss sharing) to not only reduce their exposure to risk and uncertainty, but to streamline profitability outcomes, both for themselves and their customers (Abdul-Majid et al., 2017).

For consumers, the central role of the bank is often critical to both personal and commercial interests, drawing connections between the surplus (e.g. depositors) and the deficits (e.g. borrower, debtor) through agency and instrumentality (Satibi et al., 2018). Although many Islamic banks are local, small-scale entities, as the popularity of this alternative modality continues to expand, Ibrahim and Rizvi (2017) have challenged that there is a need to consider the performance effects of scale on organisational efficiency and stability over time. Through an empirical assessment of time-series data, the researchers demonstrate a need for improved regulatory oversight in the Islamic banking industry, and immediate pressure for banks to be consolidated into larger entities in order to achieve predictable, sustainable performance outcomes (Ibrahim and Rizvi, 2017). At the same time, Faisal (2018) suggests that because liquid assets under Shariah banking regulations are controlled in the same way as regulatory capital requirements for conventional institutions, it is possible to develop an oversight system that can support the interests and administration of both types of banking.

Prior research in this field has undertaken to distil the performance-level differences between Islamic and Conventional banking practices by focusing on key periods of variation, namely financial crises or shifting economic stability. For example, evidence captured by Ara (2016) prior to the 2008 financial crisis compared the efficiency of conventional and Islamic banks by applying the stochastic frontier analysis methodology, a technique that had been previously employed by Mohamad et al. (2008) and Hamilton et al. (2010) to measure similar similarities and variations in banking modalities. The efficiency comparison revealed an overall profit efficiency advantage amongst Islamic banks, whilst the overall cost efficiency of conventional banks was higher than that of Islamic banks (Ara, 2016). Statistically, Belanes et al. (2015) have confirmed that between 2007 and 2011, there was a decrease in all areas of efficiency including overall technical efficiency (OTE), pure technical efficiency (PE), and scale efficiency (SE) across Islamic banking institutions which can be statistically correlated with the intra-period impact of the US/UK sub-prime banking crisis. However, the evidence also indicated that Islamic banks remained efficient by mobilising large amounts of deposits, maintaining nearly universal consumer confidence which Belanes et al. (2015) attribute to Sharia compliance and the religious and cultural motivations of Muslim depositors.

\subsubsection{Performance Indicators}

From a performance-based perspective, Choudhury and Hoque (2006, p.117) acknowledge that Islamic banks incur additional payroll expenses that result from the maintenance of a Shariah supervisory board (SSB) which serves as the 'supra authority' and central governance and clearinghouse. Further, Willison (2009) has outlined 
an escalated cost basis for complex, legally and certified investment instruments that characterise Shariah-compliant Islamic financial product. Both control measures have implications for the overall profitability of Islamic banks as administrative and business development expenses affect the relative efficiency and performance of the investment solution. Exemplifying this effect, Alexakis et al. (2019) performed a time-series comparison of performance between Islamic and conventional banks between 2006 and 2012 , confirming a lower cost performance that can be linked to higher administrative expenses related to the SSB and the Shariah-compliant products.

From the perspective of stability factors, Faye et al. (2013) assessed for a specific indicator (z) by dividing the sum of the return on assets and the equity to assets ratio by the standard deviation of the return on assets. This volatility proxy provided a prediction of organisational insolvency, an output that reflected an inverse probability of firm vulnerability to insolvency due to investment volatility. By applying this model to a narrow banded sample of African Islamic banks, the results revealed that when compared with conventional banks in the same region, Islamic institutions had lower non-performing loans (NPLs) and higher efficiency ratings, findings which may be attributable to the asset-backed investment strategies employed by these banks (Faye et al., 2013). By employing a similar, Z-factor model to a broader, multinational comparison, Bitar et al. (2017) confirmed that Islamic banks are more effectively sheltered from market shocks and economic uncertainty by the liquidity buffers imposed by Shariah law. At the same time, the evidence suggests that the profitability amongst Islamic banks between 2006 and 2012 was found to be higher than conventional banks due to higher return on asset (ROA) and return on equity (ROE) ratios.

Whilst studies conducted by Faye et al. (2013) and Bitar et al. (2017) have suggested that during the period of economic crisis, Islamic banks were better equipped to navigate market volatility, in the post-crisis recovery period, pairwise comparisons from multiple global markets captured by Alqahtani et al. (2017) indicate a significant decline in efficiency gaps, with conventional banks outperforming their Islamic counterparts. Whereas global data indicates a direct similarity in efficiency between conventional and Islamic banks over the period from 2006-2012, within the GCC, conventional banks have been found to outperform Islamic banks, particularly when Islamic banks are state-owned institutions (Alquahtani et al., 2017). Such findings have been further confirmed by Mohanty et al. (2016) who revealed a high degree of intra-regional volatility affecting banking efficiency in Islamic banks that has led to regionally-specific volatility in cost and profit efficiencies when compared with conventional banking institutions. Whereby this efficiency variation might signal a higher degree of insecurity or inconsistency in Islamic banks, a multi-decadal study presented by Nosheen and Rashid (2019) revealed greater performance over conventional institutions during periods of volatility in terms of both credit quality and institutional stability, a finding that is directly related to financial provisioning.

In spite of evidence (e.g. Choudhury and Hoque, 2006; Alexakis et al., 2019) suggesting that Islamic banks are outperforming their conventional counterparts, Abdul-Majid et al. (2017) offer contrarian findings, suggesting that Islamic banks are subject to a high level of variability in their performance structures, with group efficiencies during the study's sample period falling significantly below that of conventional institutions. One of the implications of such contrasting evidence is that when assessing Islamic banking outside of a narrow geographic niche, the evidence presented by Abdul-Majid et al. (2017) avoids the regional smoothing effects of narrow industry similarities (e.g. competitive technologies and resources). In contrast, most conventional banks employ similar technologies and efficiency-controlling mechanisms, reducing their degree of variation from the grouped efficiency mean, and establishing a baseline of intra-industry similarity that is distinct from the variable structures of the Islamic banking industry (Abdul-Majid et al., 2017).

Saffullah and Shamsuddin (2019, p.134) have confirmed through stochastic meta-frontier (SMF) analysis that Islamic banks have a 'higher risk-adjusted cost efficiency but a lower risk-adjusted profit efficiency relative to conventional banks.' Whilst higher risk taking can potentially improve cost performance for banks, Islamic banks with risk-adverse strategies have the ability to achieve higher revenue performance over time (Saffulah and Shamsuddin, 2019). In order to ensure the smoothed-out return payment, Islamic banks maintain a profit equalisation reserve (PER) and an investment risk reserve (IRR) which allow them to remain competitive and resolve commercial pressures and risk by limiting some of the institutional profit share when needed (Alzahrani and Megginson, 2017). Following the financial crisis, Alexakis et al. (2019) have proposed that Islamic banks took longer to align with the profitability rates of conventional banks, an outcome which they suggest may be related to the smoothing practices and earnings management techniques employed by conventional banks during this recovery period. 


\subsection{Central Hypotheses}

The prior research in this field has revealed a range of variations in Islamic banking performance during the financial crisis, but it is important to predict the long-term performance of this industry, particularly as it expands across the global community. The current study predicts the following core hypotheses which will be tested via a systematic review of the recent research regarding institutional performance:

Hypothesis 1: Following the financial crisis, Islamic banks will continue to demonstrate steady growth and performance improvements as they establish their positions in an increasingly competitive institutional market.

Hypothesis 2: Islamic banks that are unable to achieve high levels of efficiency will continue to under-perform as they fail to utilise economies of scale and dynamic investment strategies to improve their financial returns and performance.

\section{Method}

\subsection{Research Paradigm}

The scope of research surrounding Islamic banking is largely quantitative and derived from a positivist perspective of longitudinal comparisons and time-series datasets. Szafran (2012) acknowledges that the positivist approach to data comparison is advantageous when the methods can be systematically replicated, or when the outputs are dependent upon a comparison of variables in which the relationship requires structural definition. By applying this approach to the current study, the quantitative results from prior research focus on the performance variations between Islamic and conventional banks has been explored, drawing meaningful insights from a research-spanning quantitative investigation.

\subsection{Data Collection and Key Indicators}

The primary indicators used for institutional comparison in this study included institutional efficiency and banking performance, a secondary proposition involved a range of different indicators depending upon the studies and their comparison of Islamic and conventional institutions. Banking efficiency is calculated in terms of the ability for institutions to realise their financial objectives by utilising a minimal number of resources (Belanes et al., 2015).In particular, efficiency is measured in relation to output and input efficiencies, critical indicators that can each have significant implications over the long-term. Input efficiency emphasises the economic efficiency of firm inputs or resources, whilst output efficiency addresses scalar efficiency and the optimised combination of various outputs, technical efficiency (Belanes et al., 2015). By definition, technical efficiency 'expresses the ability of a firm to obtain maximal outputs from a given set of inputs' (Boscia et al., 2007, p.100). Scale efficiency in the current study was extrapolated from Hafez and Halim (2019) who identified this indicator as the ability of a firm to utilise its scale of operations relative to the size of the market in order to return the maximal results.

Productivity indicators vary throughout the prior research in this study, with emphasis placed on returns and profitability as researchers strive to illuminate the relationship between inputs and outputs. Malmquist productivity is derived from a distance function wherein multiple outputs are compared with multiple inputs in order to derive a bank's technical efficiency and assess productivity change over a set time frame (Alexakis et al., 2019). In comparing the descriptive statistics for a data envelopment analysis (DEA) and stochastic frontier analysis (SFA), Alexakis et al. (2019) identified the following core descriptive statistics including the total loans, other earning assets, deposits \& short term funding, fixed assets, general and admin expenses, and equity, for conventional and Islamic banks over the sample time frame (2006-2012). By developing quantitative ratios for key indicators including return on assets (ROA), return on deposits (ROD), cost-income ratio (CIR), and operating profit margin (OPM) it was possible to compare Islamic and conventional bank performance over the time-series data captured by these researchers.

\subsection{Study Selection Criteria}

The selection of appropriate studies for this research was based upon two elements of the standardised systematic review process outlined by Cochrane (2019) including the PICO inclusion/exclusion criteria framework and the PRISMA flow model. Table 1 presents the PICO(s) framework for study inclusion in this research process, highlighting several critical controls including post-crisis financial data, quantitative insights, and comparative studies addressing the differences between Islamic and conventional banking performance. There was also an expectation that the indicators would be based upon efficiency or performance-based datasets, allowing for time-series comparisons over post-crisis stabilisation and recovery period. In addition to these core inclusion criteria, the studies were limited temporally to journal articles published between 2017 and 2019, thereby further narrowing the search criteria to restrict potential outlying results. 
Table 1. PICO(s) Framework for study selection

\begin{tabular}{lll}
\hline PICO(s) & Inclusion Criteria & Exclusion Criteria \\
\hline Population, Patient, or Problem & Islamic and Conventional Banks & Only Islamic or Only Conventional Banks \\
Intervention & Post-Crisis Performance Outcomes & Pre or During Crisis Performance Outcomes \\
Comparator & Efficiency and Institutional Performance & Any Other Indicators (e.g. Marketing Strategies) \\
Outcomes & Quantitative Models and Findings & Qualitative Outcomes \\
Study Design & Quantitative, Comparative, Time-Series & Qualitative, Empirical, Population Data-Oriented \\
\hline
\end{tabular}

The second element in this study design was the PRISMA (2019) flow model, a systematised element used to facilitate the search and selection of online databases for studies that would be appropriate for this investigative process. The keyword search process included several specific delimiters including "Islamic" AND "Banking" AND "Performance" AND "Conventional"; however, following the initial search using multiple databases including Emerald, ScienceDirect, and Taylor \& Francis, the results numbered greater than 3,000. Accordingly, additional search terms were added to the search function to narrow the results including "Comparison" AND "Post-Crisis" and "Efficiency." Figure 1 provides a visual representation of the flow model which distilled the end results of this systematic review from just over 1,700 to just 4 studies that met the specific criteria regarding post-crisis institutional comparisons and considerations.

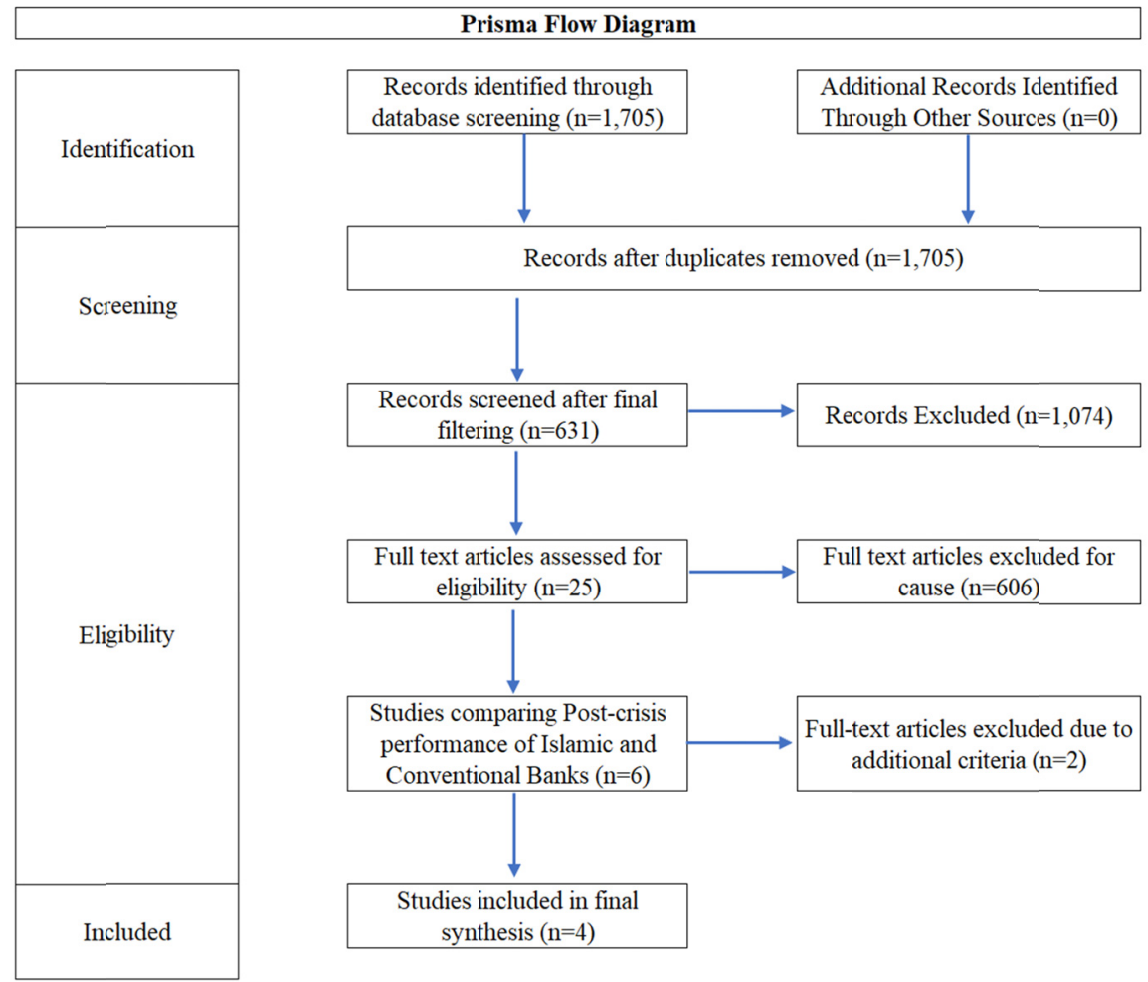

Figure 1. Prisma flow diagram

\section{Results}

\subsection{Study Selection}

There are very few studies in this field that have compared conventional and Islamic banking performance and efficiency in the post-crisis recovery period. One recent study conducted by Hafez and Halim (2019) offers regionalised results from Egypt, drawing comparisons between conventional, conventional with Islamic options, and purely Islamic banks. Another study conducted by Salman and Nawaz (2018) restricted a similar comparative focus to Pakistan, resulting in small scale comparison of both conventional and Islamic banks. Satibi et al. (2018) explored the performance effects of post-crisis institutional recovery and growth across the conventional and Islamic banks in Indonesia. Finally, Alexakis et al. (2019) conducted a larger scale comparison 
of the Islamic and conventional banks operating within the GCC region. Each of these four studies was included in this secondary research process.

\subsection{Statistics and Data Analysis}

By comparing institutional efficiency in the period of economic recovery following the 2008 financial crisis, it is possible to determine whether conventional or Islamic business practices have shaped performance as a period of normalisation has gradually influenced recovery and sustainability. The range of statistical indicators identified through this systematic review include a more general interpretation of institutional efficiency and narrower performance data specific to the core indicators adopted by each of these studies.

\subsubsection{Efficiency Analysis}

The first evidence regarding comparative efficiency was captured from a small-scale study conducted by Satibi et al. (2018) in Indonesia, a market where Islamic banking is growing alongside traditional banking systems to accommodate the needs of an expanding domestic Muslim population. Table 2 highlights the overall institutional efficiency calculated for both conventional and Islamic banks between the 2008 and 2016 period. The findings reveal a higher ratio of overhead costs $(5.65 \%)$ for Islamic banks than their conventional counterparts $(4.01 \%)$. At the same time, the higher cost income ratio (CIR) for Islamic banks (87.38) than the conventional counterparts (83.08) indicates a greater degree of operational inefficiency.

Table 2. Institutional efficiency

\begin{tabular}{|c|c|c|c|c|c|c|}
\hline \multicolumn{7}{|c|}{ Institutional Efficiency } \\
\hline Factor & Institution & $\mathrm{N}$ & Min & Max & Mean & Std Dev \\
\hline \multirow{2}{*}{ Overhead Costs } & Shariah Bank & 27 & 3.09 & 12.21 & 5.65 & 2.62 \\
\hline & Conventional Bank & 72 & 1.31 & 7.52 & 4.01 & 1.6 \\
\hline \multirow{2}{*}{ Cost Income Ratio } & Shariah Bank & 27 & 73 & 99.51 & 87.38 & 8.36 \\
\hline & Conventional Bank & 72 & 54.02 & 98.52 & 83.08 & 9.67 \\
\hline
\end{tabular}

Source: Satibi et al., 2018.

A second comparison of banking efficiency was captured from a review of a post-crisis study conducted by Hafez and Halim (2019) comparing both technical and scale efficiency over time between conventional and Islamic banks in Egypt. Figure 2 visualises the Islamic bank efficiency, whilst Figure 3 highlights the conventional bank efficiency recorded for the 2009-2017 sample period. Whilst institutional efficiency was low for conventional banks immediately following the financial crisis, it increased significantly for Islamic banks as Egyptian investors and depositors transferred funds and engaged in a repositioning of their assets in order to prevent further financial losses. Following around two years of recovery, however, conventional bank efficiency increased again, eclipsing the intra-period average for Islamic banks of 0.886 , but gradually settling into a intra-decadal average of around 0.771 (overall). Whereas the scale efficiency of conventional banks (0.997) was higher than that of Islamic banks (0.925) in 2017 due to regional investment resources and various economies of scale, technical efficiency in Islamic banks has outperformed conventional banks for the past five years, as conventional institutions have struggled to recover from the financial crisis. As Islamic efficiency has changed since 2012, these findings reveal an expansion in scalar efficiency and a minor, but stabilised decline in technical efficiency that is currently driving intra-regional growth in Egypt. 


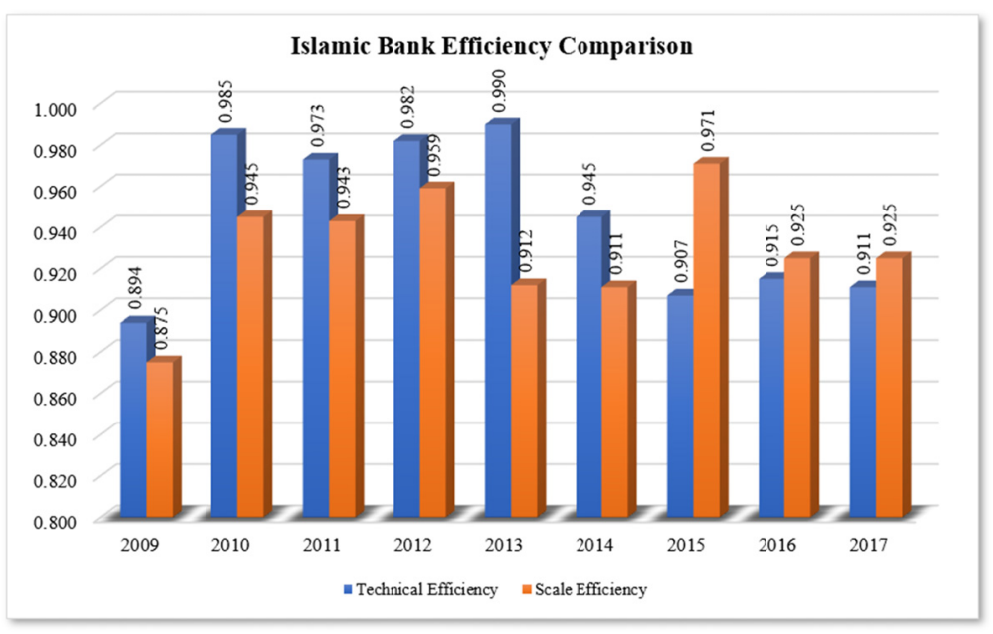

Figure 2. Islamic bank efficiency comparison

Source: Hafez and Halim, 2019.

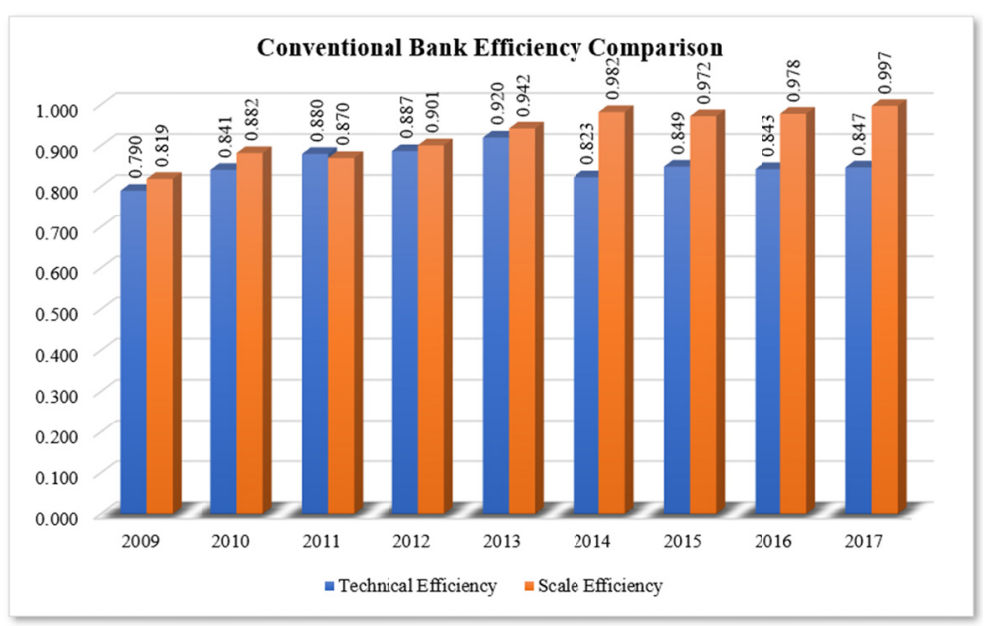

Figure 3. Conventional bank efficiency comparison

Source: Hafez and Halim, 2019.

\subsubsection{Ancillary Performance Analyses}

To assess the range of factors representing institutional performance, it is important to consider other areas beyond efficiency. Asset quality, for example, can be measured according to the ratio of non-performing loans (NPL) to the total credit extended by the banking institution. Table 3 summarises the comparative output of an NPL calculation for representative Islamic and conventional banks within the Indonesian sample. The findings reveal that the average percentage of NPLs $(4.76 \%)$ in Islamic banks is higher than the average NPL in conventional banks (1.65\%). This evidence is important, as it suggests that Islamic banks have a higher risk of vulnerability due to NPLs; however, the breadth of the range between min and max scores for conventional banks is much higher, as is the standard deviation, suggesting a greater level of volatility relative to this particular marketplace. 
Table 3. Asset quality

\begin{tabular}{llllllll}
\hline Asset Quality & & & & & & \\
\hline Factor & Institution & N & Min & Max & Mean & Std Dev \\
& Shariah Bank & 27 & 0.78 & 4.76 & 2.36 & 2.81 \\
Non-Performing Loans & Conventional Bank & 72 & 0.00 & 9.65 & 1.65 & 6.82 \\
\hline
\end{tabular}

Source: Satibi et al., 2018.

Prior research has relied upon institutional stability statistics such as the Z-score (See Faye et al., 2013; Bitar et al., 2017; Alexakis et al., 2019) to determine the comparative stability between Islamic and conventional banks. Evidence from the Satibi et al. (2018) study synthesises both the ROA and Z-score indicators into a single representation of regionalised institutional stability highlighted in Table 4. The evidence suggests that the mean return on assets (ROA) for Islamic banks of $1.43 \%$ is lower than the same score for regional conventional banks at $2.17 \%$. Further, with a low Z-score of $13.45 \%$, the findings indicate that Islamic banks are less stable than conventional banks represented by a grouped mean of $36.98 \%$.

Table 4. Stability

\begin{tabular}{|c|c|c|c|c|c|c|}
\hline \multicolumn{7}{|l|}{ Stability } \\
\hline Factor & Institution & $\mathrm{N}$ & Min & Max & Mean & Std Dev \\
\hline \multirow{2}{*}{ ROA } & Shariah Bank & 27 & 0.17 & 3.81 & 1.43 & 0.95 \\
\hline & Conventional Bank & 72 & 0.15 & 5.42 & 2.17 & 1.29 \\
\hline \multirow{2}{*}{ Z-Score } & Shariah Bank & 27 & 6.08 & 23.22 & 13.45 & 4.92 \\
\hline & Conventional Bank & 72 & 15.91 & 81.24 & 36.98 & 13.95 \\
\hline
\end{tabular}

Source: Satibi et al., 2018.

One factor that has seemingly been overlooked in more recent performance-oriented research by Alexakis et al. (2019), Hafez and Halim (2019) and Satibi et al. (2019) has been the growth rate of conventional and Islamic banks in the targeted research regions. Figure 4 highlights the post-crisis growth of conventional and Islamic banks in Egypt, a figure that suggests a distinct variation in growth performance over this period. In fact, whereas conventional deposits have grown by a combined 181.6\% during this 8-year period, Islamic bank deposits have grown by just $128.01 \%$. Year over year, conventional banks have grown by more than $14.1 \%$ on average, whilst Islamic banks have lagged, growing by just $11.01 \%$ during the same period.

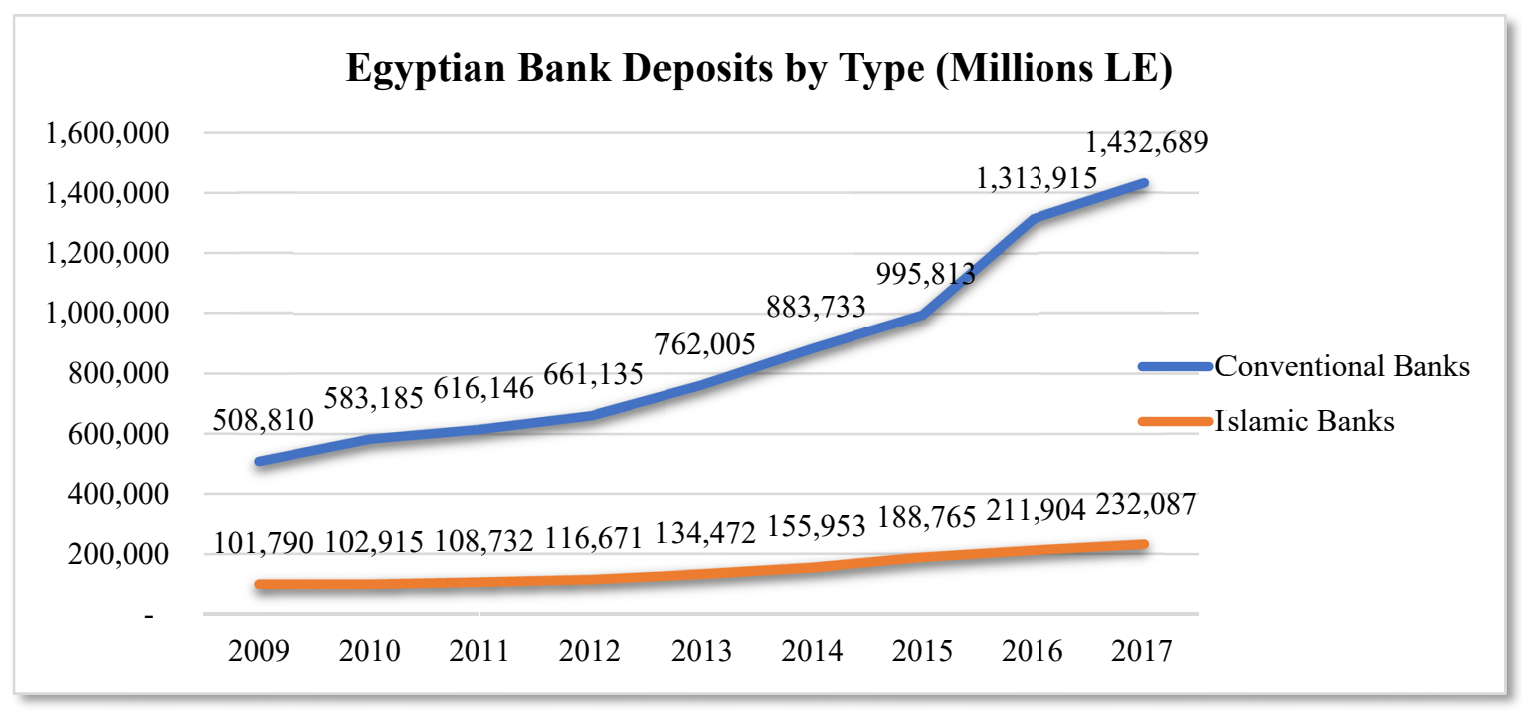

Figure 4. Egyptian bank deposits by type

Source: Hafez and Halim, 2019. 
Although the Alexakis et al. (2019) study includes a time-series representation of conventional and Islamic banking in the GCC that does not extend beyond 2012, by comparing post-crisis (e.g. 2009+) recovery data from conventional and Islamic banks, a descriptive performance relationship can be observed. Figures 5 and 6 present the comparison of the intra-periodic change in bank loans and deposits at Conventional and Islamic banks, respectively. Normalised to reflect 2005 prices, the total loans and deposits reflected in each of these two models indicate the post-crisis growth for each of these forms of GCC-based institutions. From a performance perspective, the evidence indicates a post-crisis reaction by borrowers and depositors as Islamic banking in 2009 grew by $29.4 \%$ (loans) and $28.1 \%$ (deposits) in comparison with $24.2 \%$ for conventional loans and $23.6 \%$ for conventional deposits. Whereas conventional banks experienced a form of bull-whip effect in 2010, declining in both loans $(-8.49 \%$ ) and deposits $(-7.12 \%)$, Islamic banks experienced an increase in loans of $17.92 \%$ perpetuated by a lack of consumer confidence with traditional banking institutions and $2.52 \%$ in deposits. Islamic banks, however would also encounter their own post-crisis bull-whip effect in 2011, with declines in both loans $(-25.3 \%)$ and deposits $(-7.69 \%)$, performance that was mirrored by conventional banks with lesser declines in new loans (-6.43\%) and deposits (-7.12\%). In 2012, a more normative state of growth had returned, with Islamic banks growing significantly in terms of loans $(12.79 \%)$ and deposits $(10.64 \%)$, whilst conventional banks made single-digit gains at $6.42 \%$ and $6.05 \%$. Such findings complement the evidence presented in Figure 3 in relation to the Hafez and Halim (2019) findings from Egypt, whereby growth in conventional banks under-performed Islamic banks year over year during the post-crisis recovery period, and the accelerated significantly in the past three years.

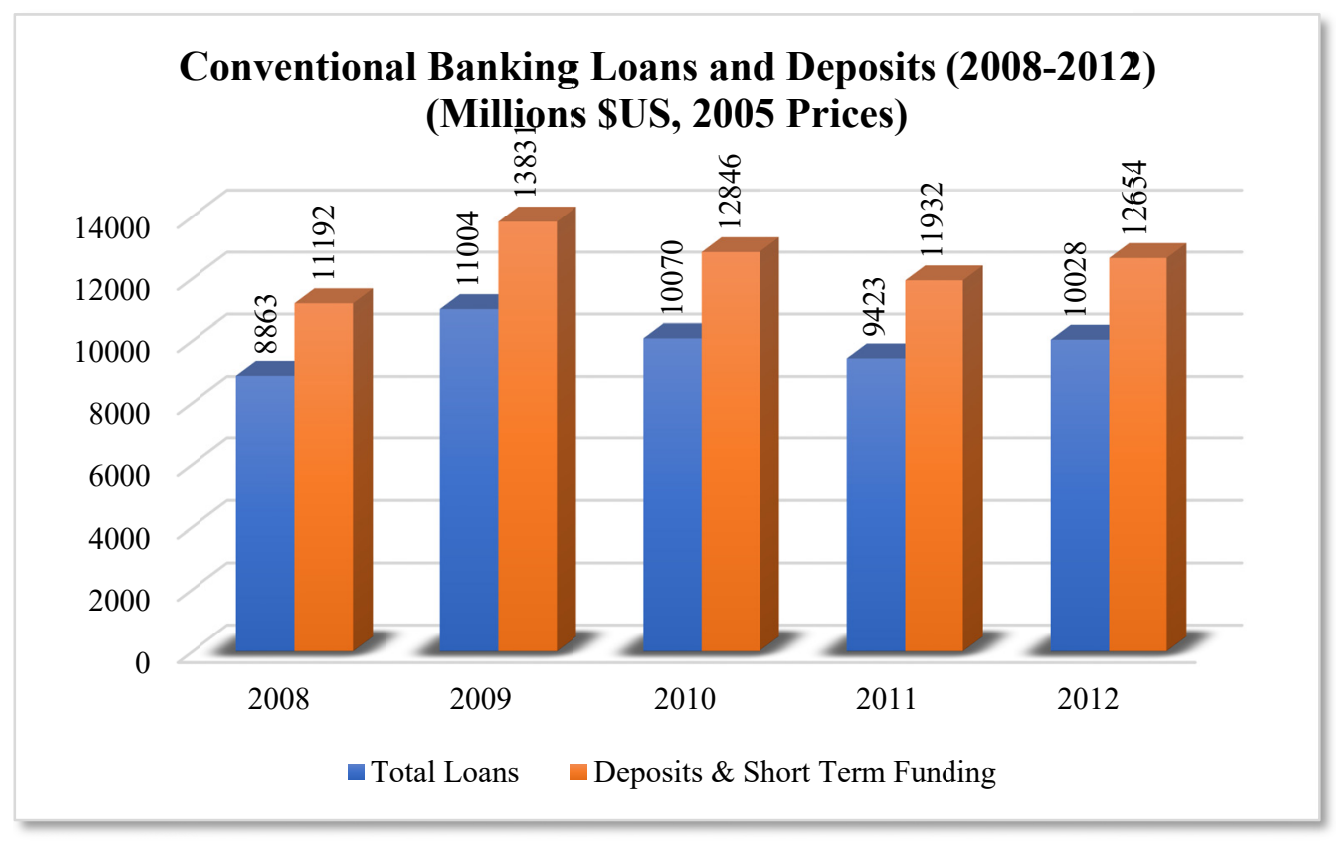

Figure 5. Conventional Banking Loans and Deposits (2008-2012) (Millions \$ US, 2005 Prices) 


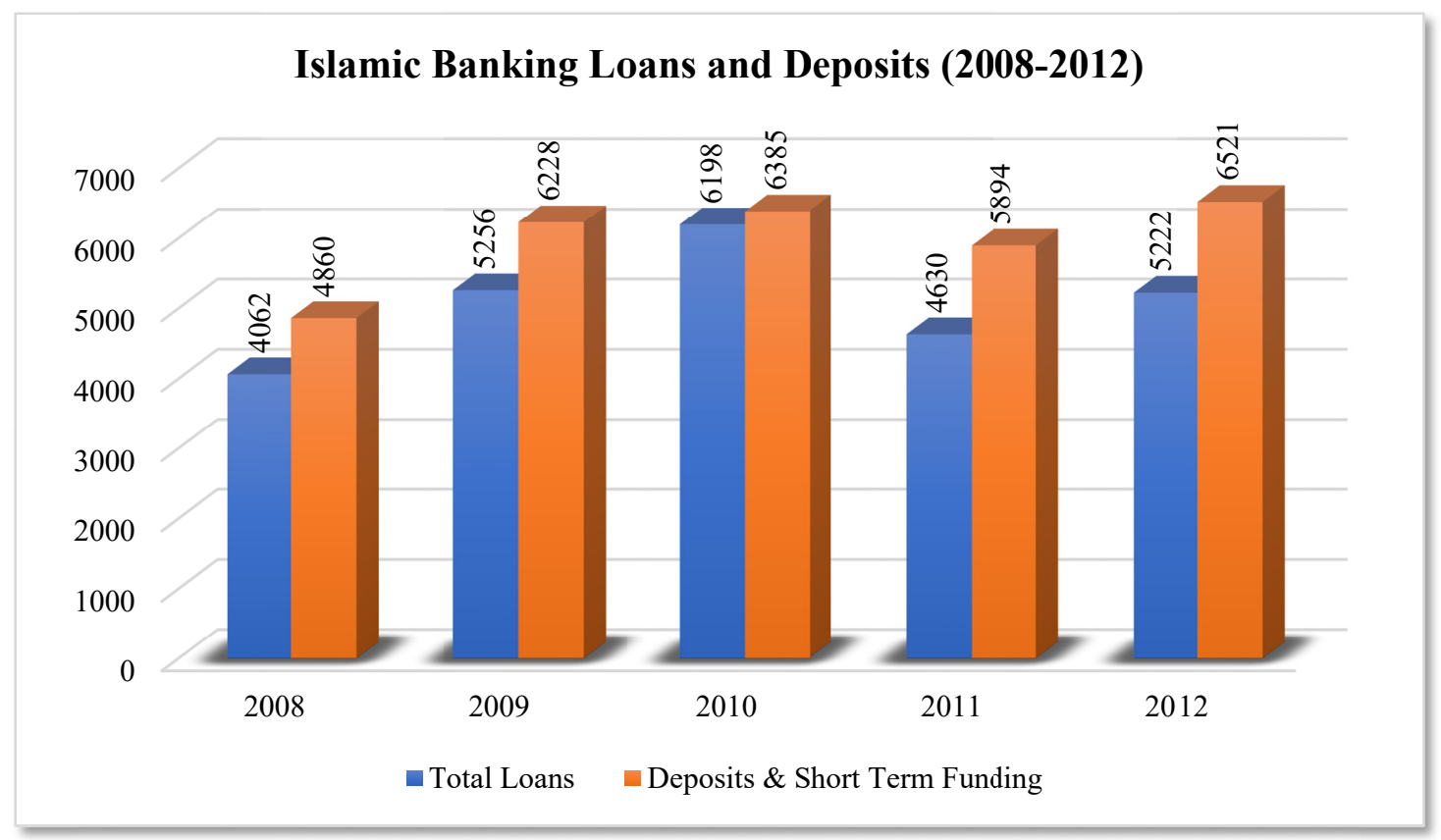

Figure 6. Islamic banking loans and deposits (2008-2012) (Millions \$US, 2005 Prices)

Source: Alexakis et al., 2019.

The final comparison was extrapolated from the regional study of two Pakistani conventional and two Pakistani Islamic banks conducted by Salman and Nawaz (2018). Figure 7 highlights the change in return on assets (ROA) since 2013 for each of these institutions, highlighting a marked decline in performance for Standard Chartered (SC), a conventional bank, but also for Meezan Bank (MB) an Islamic bank. MCB Bank maintained a relatively positive growth in ROA, whilst Bank Islami Limited (BIL) experienced a slight decline from 2014-2015 until recovering in the last two years of the model.

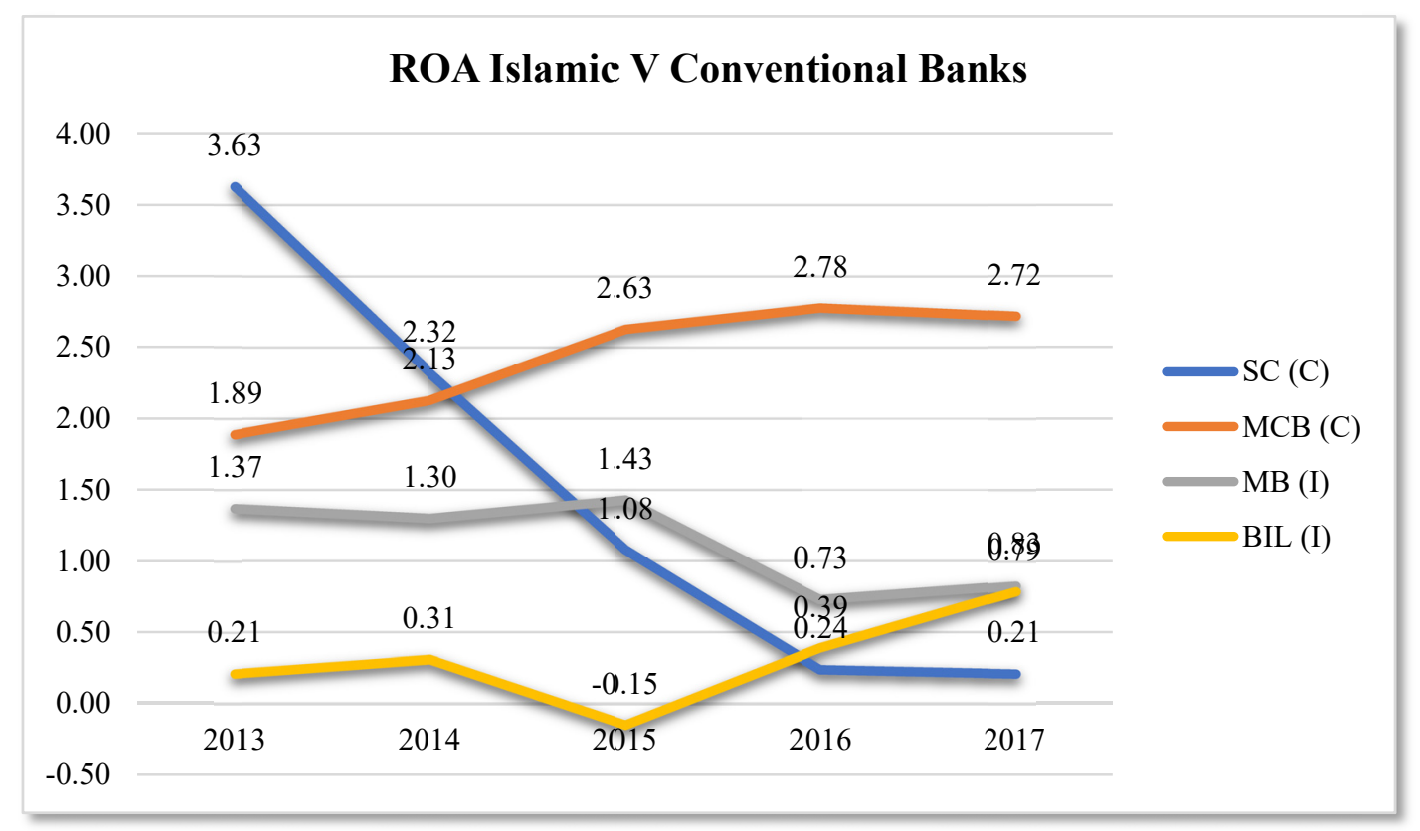

Figure 7. ROA Islamic v Conventional banks

Source: Salman and Nawaz, 2018. 
A secondary indicator, return on deposits (ROD) is visualised in Figure 8, highlighting a significantly skewed dataset as a result of the significantly high performance by BIL during the sample period. Whereas both SC and MB maintained the same trend in relation to ROA of declining returns, the performance for MCB and BIL was positive over this period, with growth expanding the ROD impact from 2013-2017.

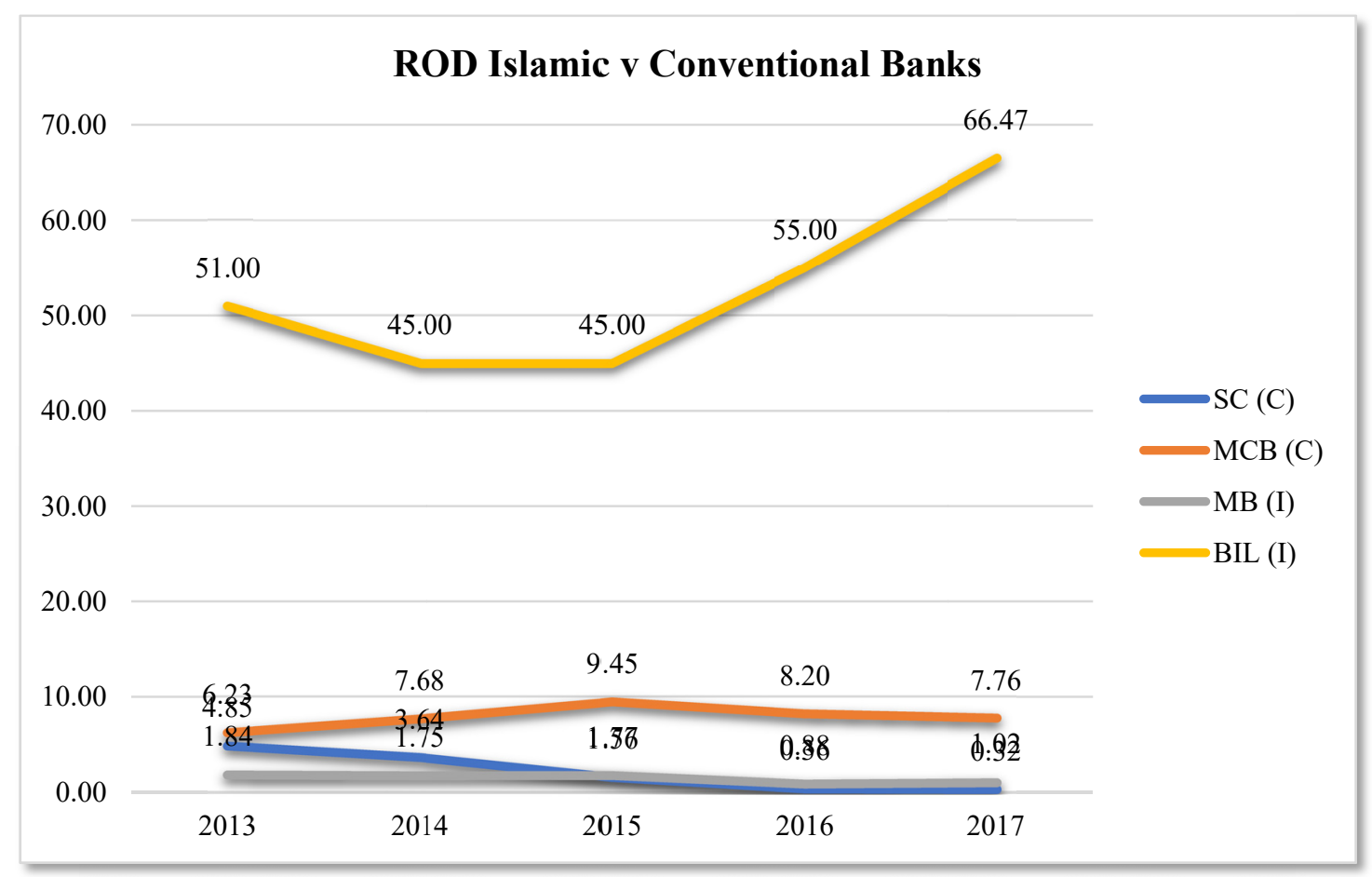

Figure 8. Figure 7 ROD Islamic V Conventional banks

Adapted From: Salman and Nawaz, 2018.

The final indicator of direct importance to banking performance visualised in Figure 9 focused on the operating profit margin (OPM) for each of these banks during this four-year period. The findings reveal a significant decline for SC and extremely low performance for MCB. Importantly, the evidence suggests a relatively steady-state profit performance for both of the Islamic banks during this period of stabilisation and growth. Whereas Salman and Nawaz (2018) suggest that there were not any bad debts written off for the Islamic banks to impact upon their performance, evidence cannot confirm this event and the results contrast with the debt vulnerability of Islamic institutions reported elsewhere in this study. 


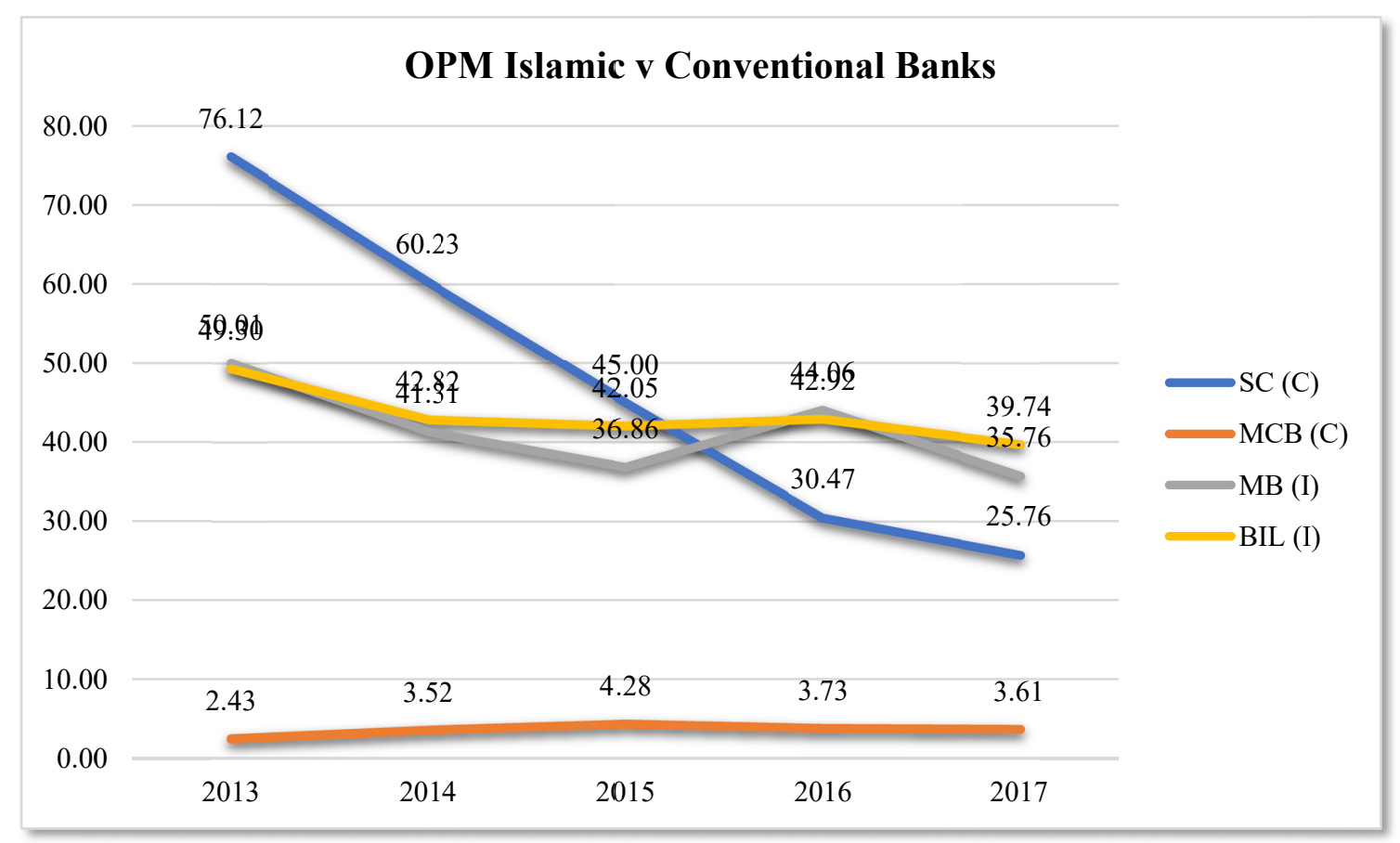

Figure 9. OPM Islamic V Conventional banks

Source: Salman and Nawaz, 2018.

\section{Discussion}

As conventional banking systems continue to demonstrate vulnerability to market volatility and systemic shocks, the potential advantages of Islamic banking have motivated a substantial body of research in the field of institutional finance. As a result of this broad scope of research, many investigations have undertaken to explore the specific differences in performance and efficiency between conventional and Islamic banks during severe economic downturns or crisis conditions. In contrast to such studies, the primary aim of this investigation was to critically assess the post-crisis performance of Islamic banks, comparing performance outcomes during the period of economic recovery that has characterised the past decade since the global financial crisis. This aim has been accomplished by conducting a post-crisis comparison of four studies that have collected time-series data from multiple institutions across the global population of conventional and Islamic banks.

One of the core findings of this study was that although Islamic banks experienced positive efficiency improvements immediately following the crisis, post-crisis efficiency has declined as these institutions have been confronted with an increasingly competitive marketplace. During the financial crisis, Ara (2016) offered evidence from institutional development prior to the financial crisis which positioned profit efficiencies of Islamic banks above that of conventional banks, whilst overarching evidence also indicated that Islamic banks (although region-specific) were performing better than conventional banks. Alexakis et al. (2019) acknowledge that the age and experience of Islamic banks in the GCC may indicate specific cautionary and fiscally responsible trends following the 2008 financial crisis as institutional leaders have guarded against uncertainty and risk through conservative, longer-term (e.g. real estate) investments. In fact, evidence presented by Bitar et al. (2018) confirms that higher performing Islamic banks are those with higher capitalisation, as they strive to strategically reduce risk in the financial sector through conservative financing decisions.

The evidence captured during this comparative review has revealed a central problem of efficiency that is continuing to restrict the profitability and performance of these Islamic banks. To improve their position in the banking industry, Nosheen and Rashid (2019) acknowledge that Islamic banks need to develop mechanisms to improve and execute fee-based instruments, thereby increasing non-interest-based revienues. In addition, the relatively small scale of Islamic institutions has competitive disadvantages, and therefore, in order to utilise economies of scale and expand their position in the financial industry, these banks should consider growing their size through new accounts or mergers and acquisitions, reducing their cost basis, and improving the selectivity of their investment decisions (Ibrahim and Rizvi, 2017; Nosheen and Rashid, 2019). The comparative evidence 
extrapolated from each of these four studies has demonstrated that in spite of positive post-crisis gains, Islamic banks have suffered from inefficiency and under-performing investments as a greater number of institutions strive to compete with Shariah-compliant instruments. Future consolidation, mergers, or accelerated growth is needed to position against these forces as Islamic banks seek to expand their banking foothold throughout the global community.

\subsection{Discussion of Hypotheses}

Two initial hypotheses were proposed for this study. HP1 predicted that Islamic banks would continue to demonstrate steady growth and performance improvements after the financial crisis as they establish their positions in the marketplace. This hypothesis was partially confirmed, with empirical evidence from some markets suggesting that such performance and growth has been outpaced by conventional counterparts in recent years, whilst others have experienced a greater growth improvement in Islamic banking. HP2 predicted that Islamic banks unable to achieve high levels of efficiency will continue to under-perform. This second hypothesis has been confirmed as Islamic banks not only lack the scalar advantages needed to leverage network efficiencies to create additional gains and growth, but they lack the technical efficiencies needed to develop new, innovative financial instruments to meet the changing needs of their Muslim consumers. The evidence predicts that over the long term, such efficiencies will manifest in the form of strategic partnerships and new organisational structures; however, in their current state, Islamic banks are resistant to accelerated change as they slowly and cautiously develop operational business models that avoid risk and mitigate any potential threat of violating Shariah law (Salman and Nawaz, 2018; Alexakis et al., 2019). On a regional level, however, evidence (e.g. Hafez and Halim, 2019) does suggest that efficiency can be improved by diversity and the expansion of the Islamic banking market; however, this process is contingent upon consistent socio-economic conditions that are largely unpredictable in the current tumult of the regional financial markets (e.g. Arab Spring in Egypt).

\subsection{Bias and Concerns}

In a globalised banking industry, the regional bias manifest in prior studies (e.g. Ara, 2016) has important implications for comparing Islamic and conventional banking practices. Specifically, the narrow banding of Islamic finance relative to region specific institutions (see Mohanty et al., 2016) has the potential to create systemic vulnerabilities that bias and restrict the trans-national applicability of the results. As an increasingly larger number of conventional banks are adopting Sharia-compliant solutions, such methodological limitations restrict the potential for exploratory comparisons and structural insights that can be linked to banking modality rather than economic system. This bias was evidenced within the Satibi et al. (2018) research, whereby the narrow population of Indonesian institutions resulted in regionalised biases that are unlikely to extend to other markets such as Egypt or Saudi Arabia where Islamic banking has grown at a much quicker, much more competitive rate. Future research should consider either focusing on intra-institutional performance effects or multinational comparisons, highlighting the specificity of Islamic banking and negating the systemic biases of regional and context-constrained investigations.

\subsubsection{Methodological Gaps and Limitations}

One of the problems with the common frontier analysis (See Mohammad et al., 2008; Srairi, 2010; Saeed and Izzeldin, 2016) observed by Safullah and Shamsuddin (2019) is that is likely to be biased, failing to account for the varying modes of operation and supervision across Islamic and conventional banks. To address these potential vulnerabilities, Huang et al. (2014) developed the stochastic meta-frontier approach which can estimate within-group efficiency and between-group efficiency of firms across varying production and market conditions. Adapted and applied by Safullah and Shamsuddin (2019), this revised quantitative approach allowed for the effects of Shariah governance to be compared with more traditional board oversight and governance in relation to the effects on Islamic banking efficiency. These variations in methodology in addition to the range of considerations revealed during this systematic review highlight the difficulties in analysing the variations in performance across Islamic and conventional banking datasets, particularly when group-specific efficiencies are not being benchmarked against like-structured institutions.

\subsection{Conclusions}

The conclusions of this study suggest that Islamic banking is a viable, sustainable, and potentially efficient source of lower-risk, Shariah-compliant financial products. However, due to the economic and systemic dependency of the Islamic banking institution on multiple regulatory controls such as the SSB and the domestic regulatory agencies for all banking institutions, post-crisis efficiency data does not match that of conventional counterparts. Further, the evidence indicates that Islamic banks are lagging in investment efficiency as a result of their inability to develop economies of scale and leverage their size and reach to develop innovative investment 
opportunities. Whilst such initiatives are largely contingent upon the demand profile of the expanding consumer base, many conventional institutions are entering the Islamic marketplace in order to compete directly with banks that do not offer conventional investment products. A diversified solution is attractive to many consumers, regardless of Shariah law, and for this reason, the failure to achieve efficiency in this marketplace is based upon the competitive pressures and the resistance to diversification of financial strategies by Islamic banks. These findings conclude that future scrutiny is needed to monitor the patterns of development and growth in this industry, comparing the time series evidence regarding institutional efficiency and performance as Islamic banking becomes an increasingly mainstream financial vehicle.

\section{References}

Abdjul-Majid, M., Falahaty, M., \& Jusoh, M. (2017). Performance of Islamic and conventional banks: A meta-frontier approach. Research in International Business and Finance, 42, 1327-1335. https://doi.org/10.1016/j.pacfin.2015.02.012

Alexakis, C., Izzeldin, M., Johnes, J., \& Pappas, V. (2019). Performance and productivity in Islamic and conventional banks: Evidence from the global financial crisis. Economic Modelling, 79, 1-14. https://doi.org/10.1016/j.econmod.2018.09.030

Alqahtani, F., Mayes, D. G., \& Brown, K. (2017). Islamic bank efficiency compared to conventional banks during the global crisis in the GCC region. International Journal of International Financial Markets, Institutions, and Money, 51, 58-74. https://doi.org/10.1016/j.intfin.2017.08.010

Alzahrani, M., \& Megginson, L. W. (2017). Finance as worship: A survey of Islamic finance research. CEIF Discussion Paper, https://papers.ssrn.com/sol3/papers.cfm?abstract_id=2967619.

Ara, S. (2016). Profit and cost efficiencies of conventional banking (CB) and Islamic banking (IB) Using stochastic frontier approach: A comparative study. Journal of Islamic Economics, Banking and Finance, 12(1), 63-89. https://doi.org/10.12816/0028312

Belanes, A., Ftiti, Z., \& Regaig, R. (2015). What can we learn about Islamic banks efficiency under the subprime crisis? Evidence from GCC region. Pacific-Basin Journal, 33, 81-92. https://doi.org/10.1016/j.pacfin.2015.02.012

Bitar, M., Hassan, M. K., \& Hippler, W. J. (2018). The determinants of Islamic bank capital decisions. Emerging Markets Review, 35, 48-68. https://doi.org/10.1016/j.ememar.2017.12.002

Bitar, M., Madies, P., \& Taramasco, O. (2017). What makes Islamic banks different? A multivariate approach. Economic Systems, 41, 215-235. https://doi.org/10.1016/j.ecosys.2016.06.003

Boscia, V., Carretta, A., \& Schwizer, P. (2007). Co-Operative Banking. Basingstoke: Palgrave Macmillan.

Boumediene, A., \& Caby, J. (2009). The stability of Islamic banks during the subprime crisis. https://papers.ssrn.com/sol3/papers.cfm?abstract_id $=1524775$.

Chapra, M. U. (2008). The global financial crisis: Can Islamic finance help minimize the severity and frequency of such a crisis in the future? Saudi Arabia: Islamic Development Bank Group, https://unctad.org/meetings/en/Contribution/gsd_sd_2012-02-25_bp_chapra_en.PDF.

Choudhury, M. A., \& Hoque, M. Z. (2006). Corporate governance in Islamic perspective. Corporate Governance International Journal Business Society, 6, 116-128. https://doi.org/10.1108/14720700610655132

Cochrane. (2019). Handbook for systematic reviews. Cochrane, https://us.cochrane.org/.

Faisal, A. (2018). Risk and efficiency in banking: A comparative study between Islamic and Conventional banking. University of Plymouth. Retrieved from https://pearl.plymouth.ac.uk/handle/10026.1/11241.

Faye, I., Triki, T., \& Kangoye, T. (2013). The Islamic finance promises: Evidence from Africa. Review of Development Finance, 3, 136-151. http://doi.org/10.1016/j.rdf.2013.08.003

Hafez, H. M., \& Halim, M. (2019). The efficiency of Islamic banks versus conventional banks: An empirical study of an emerging economy. Banks and Bank Systems, 14(2), 50-62. http://doi.org/10.21511/bbs.14(2).2019.05

Hamilton, R., Quarawi, W., \& Al-Jarrah, M. (2010). Cost and profit efficiency in the Jordanian banking sector 1993-2006: A parametric approach. International Research Journal of Finance and Economics, 56, 111-123. http://doi.org/10.12816/0028312

Huang, C. J., Huang, T. H., \& Liu, N. H. (2014). A new approach to estimating the metafrontier production 
function based on a stochastic frontier framework. Journal of productivity Analysis, 42, 241-254. https://doi.org/10.1007/s11123-014-0402-2

Ibrahim, M. H., \& Rizi, S. A. R. (2017). Do we need bigger Islamic banks? An assessment of bank stability. Journal of Multinational Financial Management, 40, 77-91. https://doi.org/10.1016/j.mulfin.2017.05.002

Mohamad, S., Hassan, T., \& Bader, M. K. (2008). Efficiency of conventional versus Islamic banks: International evidence using the stochastic frontier approach (SFA). Journal of Islamic Economics, Banking, and Finance, 4(2), 107-130.

Mohanty, S. K., Lin, H. J., Aljuhani, E. A., \& Bardesi, H. J. (2016). Banking efficiency in the Gulf Cooperation Council (GCC) countries: A comparative study. Review of Financial Economics, 31, 99-107. https://doi.org/10.1016/j.rfe.2016.06.004

Nosheen, I., \& Rashid, A. (2019). Business orientation, efficiency, and credit quality across business cycle: Islamic versus conventional banking. Are there any lessons for Europe and the Baltic states? Baltic Journal of Economics, 19(1), 105-135. https://doi.org/10.1080/1406099X.2018.1560947

PRISMA. (2019). Transparent reporting of systematic reviews. PRISMA, http://www.prisma-statement.org/.

Saeed, M., \& Izzeldin, M. (2016). Examining the relationship between default risk and efficiency in Islamic and conventional banks. Journal of Economic Behaviour in Organisations, 132, 127-154. https://doi.org/10.1016/j.jebo.2014.02.014

Safiullah, M. D., \& Shamsuddin, A. (2019). Risk-adjusted efficiency and corporate governance: Evidence from Islamic and conventional banks. Journal of Corporate Finance, 55, 105-140. https://doi.org/10.1016/j.jcorpfin.2018.08.009

Salman, A., \& Nawaz, H. (2018). Islamic financial system and conventional banking: A comparison. Arab Economic and Business Journal, 13, 155-167. https://doi.org/10.1016/j.aebj.2018.09.003

Satibi, E., Utami, W., \& Nugroho, L. (2018). A comparison of Sharia banks and conventional banks in terms of efficiency, asset quality, and stability in Indonesia for the period 2008-2016. International Journal of Commerce and Finance, 4(1), 134-149. ISSN 2149-9608.

Srairi, S. A. (2010). Cost and profit efficiency of conventional and Islamic banks in GCC countries. Journal of Productivity Analysis, 34, 45-62. https://doi.org/10.1007/s11123-009-0161-7

Szafran, R. F. (2012). Answering Questions with Statistics. Thousand Oaks, CA: Sage Publications.

Willison, B. (2009). Technology trends in Islamic investment banking. Islamic Finance News, 6(19), 22-23.

\section{Copyrights}

Copyright for this article is retained by the author(s), with first publication rights granted to the journal.

This is an open-access article distributed under the terms and conditions of the Creative Commons Attribution license (http://creativecommons.org/licenses/by/4.0/). 